\title{
Regionalized classification of multivariate geochemical data from Jacupiranga Alkaline Complex (Ribeira de Iguape Valley/São Paulo, Brazil)
}

\author{
Paulo M. Barbosa Landim ${ }^{1}$, Talita C. Oliveira Ferreira ${ }^{2}$ \& Jorge Silva Bettencourt ${ }^{3}$
}

\begin{abstract}
This paper describes the use of discriminant analysis to obtain regionalized classification of some carbonatite units. The carbonatites are part of the Jacupiranga Ultramafic-Carbonatite Complex, hosted by PreCambrian rocks of the Açungui Group, and are located in the southwest part of the State of São Paulo, Brazil. Twelve carbonatite units have been identified but the present study focuses on three of them: the Foliated Carbonatite (CBF), White Carbonatite (CBR), and North Carbonatite (CBN) units. The data available for the three units included geological and mineralogical observations, as well as concentrations of $\mathrm{CaO}, \mathrm{MgO}, \mathrm{SiO}_{2}, \mathrm{Fe}_{2} \mathrm{O}_{3}$, $\mathrm{P}_{2} \mathrm{O}_{5}, \mathrm{MnO}, \mathrm{NaO}, \mathrm{K}_{2} \mathrm{O}, \mathrm{TiO}_{2}, \mathrm{SrO}$, and loss in ignition. The results clearly distinguish the $\mathrm{CBN}$ unit from the $\mathrm{CBF}$ unit and the $\mathrm{CBN}$ unit from the $\mathrm{CBR}$ unit. Therefore, $\mathrm{CBN}$ and $\mathrm{CBF}$ units cannot be grouped together for mining operations; rather, they should be mined as separate bodies because they represent different populations with respect to their rheological characteristics and chemical compositions. In contrast, the results show no significant distinction between the CBR and CBF units. Since the CBR and CBF units are closely related, they may probably be assembled in the same mining block and do not require a differentiated quarry.
\end{abstract}

Keywords: Regionalized classification, discriminant analysis, carbonatite quarry..

Resumo Classificação regionalizada de dados geoquímicos multivariados provenientes do Complexo Alcalino de Jacupiranga (Vale do Ribeira de Iguape/São Paulo - Brasil). Foi aplicada a análise discriminante para a classificação regional de algumas unidades geológicas existentes no Complexo Ultramáfico-Carbonatítico de Jacupiranga, de idade cretácea, localizado no Sudoeste do Estado de São Paulo/Brasil, e alojado em rochas pré-cambrianas do Grupo Açungui. Já haviam sido identificadas 12 unidades, classificadas segundo o objetivo de beneficiamento do minério, mas neste estudo apenas os carbonatitos foliado (CBF), branco (CBR) e norte (CBN) foram enfocados. Nessas rochas foram obtidos teores dos óxidos $\mathrm{SiO}_{2}, \mathrm{Fe}_{2} \mathrm{O}_{3 \mathrm{t}}$, $\mathrm{CaO}, \mathrm{MgO}, \mathrm{P}_{2} \mathrm{O}_{5}, \mathrm{MnO}, \mathrm{SrO}, \mathrm{BaO}$ e perda ao fogo em 95 amostras analisadas. Os resultados da análise discriminante, tanto quando mostrados em gráficos a dois fatores, usuais nesse tipo de análise, como em mapas de probabilidade de ocorrência, mostram uma nítida distinção entre os teores expressos pelas unidades $\mathrm{CBN}$ e $\mathrm{CBF}$, sendo consideradas distintas. Com respeito à unidade $\mathrm{CBR}$, não está significativamente discriminada de CBF, mas sim de CBN. Tais resultados indicam, com referência aos aspectos mineiros, que CBF e CBN, por constituírem unidades distintas, não podem ser estimadas concomitantemente, pois representam populações diferentes com relação às concentrações de elementos. A unidade $\mathrm{CBR}$ tem intima ligação com CBF, verificada tanto em campo como pela análise discriminante, não exigindo, portanto, uma lavra diferenciada.

Palavras-chave: Classificação regionalizada, análise discriminante, lavra de carbonatito.

INTRODUCTION Analysis of geochemical data requires measurement of regional attributes because the results are used to form working hypotheses that will try to explain those spatial processes that controlled the formation of the phenomenon under study. As geochemical processes are very complex and sampling is usually insufficient, a simplification of reality is imposed by modeling. Regionalized classification of samples into groups is one such model that can transfer the results of a statistical multivariate analysis from theoretical multidimensional space to a two-dimensional map or even to a three-dimensional diagram.

Regionalized classification is defined as the probabilistic assignment of multivariate and georeferenced samples to groups by using discriminant analysis. According to Olea (1999) and his predecessors Harff and Davis (1990), there is nothing conceptually new in regionalized classification, but some novelty is introduced by jointly applying a number of well-known mathematical, statistical, and geostatistical techniques. Bohling (1997) presents software for regionalized classification and includes several options for the method of implementation. According to Pacheco and Landim (2005) the main problems associated with this methodology are the geological interpretation of the groups, whether they are spatially separated, and sample attri-

1 - Universidade Estadual Paulista/UNESP, Instituto de Geociências e Ciências Exatas, Rio Claro (SP), Brazil. Corresponding author: plandim@rc.unesp.br

2 - Multigeo, Mining, Geology and Environment Ltd., Brazil

3 - Universidade de São Paulo/USP, Instituto de Geociências, São Paulo (SP), Brazil. 
butions that do not present well-defined probabilities for belonging to one predetermined group or another.

In this work the methodology was applied to a number of carbonatite bodies that occurs in Cajati Mine. These rocks are associated with Jacupiranga's Alkaline Complex, located in the Ribeira de Iguape region of the southern part of the State of São Paulo, Brazil. There Bunge Fertilizers S.A. exploits apatite as an industrial mineral. The targets of this study are the faciological units North Carbonatite (CBN), Foliated Carbonatite (CBF), and White Carbonatite (CBR). The research goal was to perform a comparative evaluation of geochemical attributes with the purpose of improving mining models and planning optimization.

GEOLOGY OF THE AREA The Cretaceous Ultramafic-Carbonatite Complex of Jacupiranga, located in the State of São Paulo Southwest, is a NNW oval structure of about $70 \mathrm{~km}^{2}$ (Ruberti et al., 1992), lodged in Precambrian rocks of the Açungui Group (Melcher, 1962). The carbonatite body is elliptical $(1000 \times 400 \mathrm{~m})$ and is hosted in clinopyroxenite, which is known in Brazil as jacupiranguito. Since the 1940s the apatite present in carbonatite has been exploited by Bunge Fertilizers S.A. to produce products for animal nutrition, fertilizers, and alimentary industries. Until the end of the 1990s there were five well-known carbonatite facies (Gaspar, 1989) whose limits and three-dimensional distribution were imprecise for mine planning. As the mining advanced it became necessary to obtain a more precisely detailed description of ore distributions. From recent geological surveys (Saito et al., 2004) twelve geological units have been identified; these are illustrated in figure 1 .

By associating the results of Gaspar (1989) with the mappings of Saito et al. (2004), it was possible to differentiate from among the twelve units those that are exclusively carbonatitic (1, 2, 3, 6, 7, 8 and 9): they exhibit distinct petrological characteristics, including mapable contacts deeping up to $70-90^{\circ}$ with xenoliths in the contact region (jacupiranguito - XELeste and XESul or older carbonatite). Each unit presents a distinct internal organization with concentric flow foliation. The north and south phosphoric zones occur as isolated lens, meters in size. The Dolomitic Carbonatite (DOL) presents coarse to pegmatite texture, transitional contact, and includes relicts of foliated rock, which apparently originate from late carbonatic alteration (dolomitization). The xenolithic north zone (XENorte) is an oval body that isolates the south carbonatites from the north 9,10 , and 11 carbonatites. These xenoliths are composed of decimeter- to me-
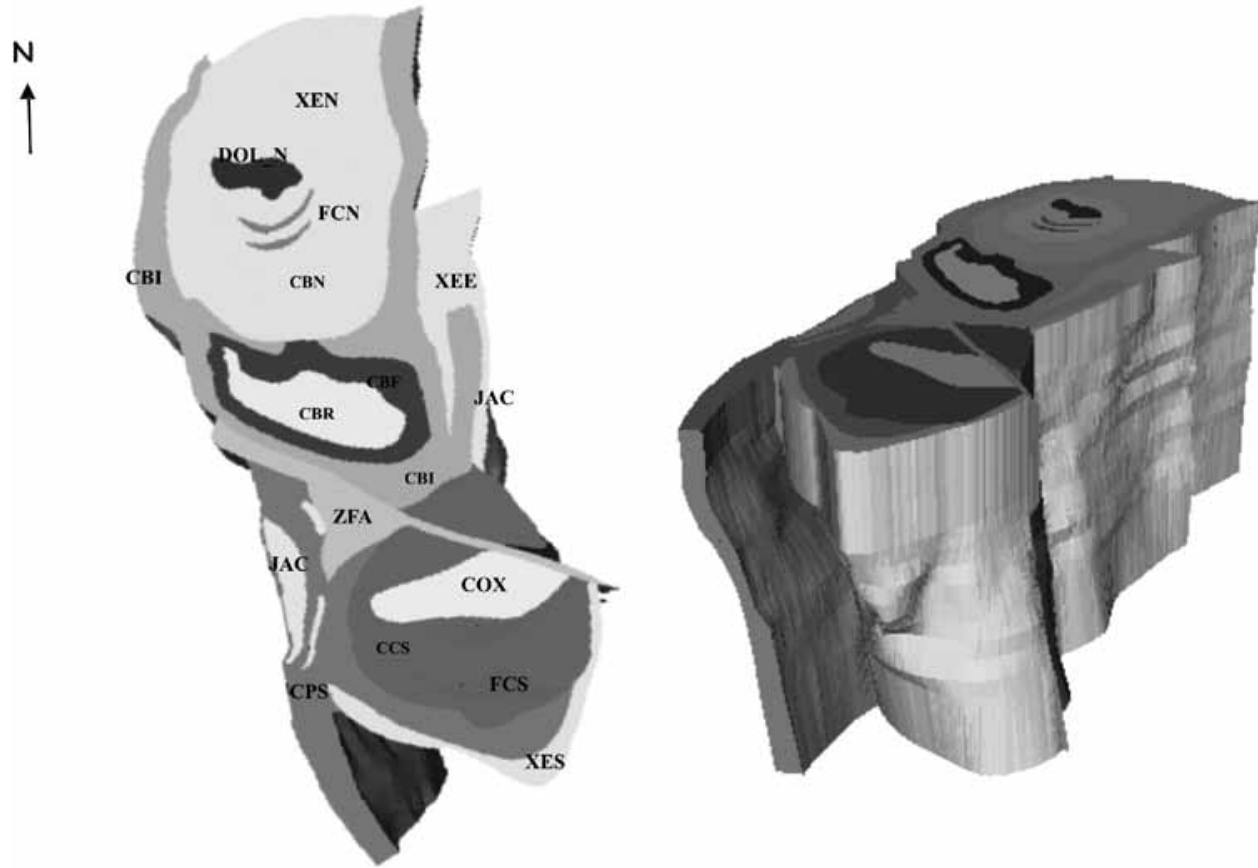

Figure 1 - Geological map and block diagram showing the different lithological units present in the Jacupiranga Complex: 1) Peripheral South Carbonatite (PSC), 2) Limestone South Carbonatite (CCS), 3) Oxide Carbonatite (COX), 4) Areas with Foscorite South (FCS), 5) Fault Zone (ZFA), 6) Intermediary Carbonatite (CBI), 7) Foliated Carbonatite (CBF), 8) White Carbonatite (CBR), 9) North Carbonatite (CBN), 10) Areas with Foscorite North (FCN), 11) Dolomitic Carbonatite (DOL), 12) Xenolithic Areas (XENorte, XELeste, XESul), 0) Jacupiranguito Bodies (JAC). The units studied in this work are labeled here in bold. (Modified from Saito et al. 2004). 
ter-sized blocks of jacupiranguito, and their contact with the carbonatite matrix shows metassomatized edges. The last important geological episode is represented by a ruptil shearing regime that produced a system of main and subsidiary faults; most prominent is the main fault which is $\mathrm{N} 75 \mathrm{~W} /$ subvertical and has a sinistral shearing component (ZFA). Faulting originated breccia, cataclasite, and fault floor, besides allowing alteration/oxidation of carbonatite in different directions and intensities. The results from the detailed geological mapping allowed better understanding of the internal organization of the carbonatite body and, as a consequence, improved models for the deposit exploration and for mine development.

\section{MATERIALS AND METHODS}

Geochemical Analysis Whole-rock samples of CBR, $\mathrm{CBF}$, and CNB facies were collected on the surface during a 1:500 geological survey; subsurface samples were obtained by drilling holes on a regular grid of 25 x 25 meters. Their depths did not exceed $35 \mathrm{~m}$ and the inclination angles with the surface varied from $45^{\circ}$ to $60^{\circ}$. A total of 95 samples were obtained for this study by subdividing the intervals on each unit within $5 \pm$ $2.5 \mathrm{~m}$ for each interval. The samples were afterwards prepared and sent to the Technological Characterization Laboratory in the Mines Department of the Polytechnic Engineering School of the University of São Paulo for analyses by X-ray fluorescence.

The analyzed oxides were $\mathrm{CaO}, \mathrm{MgO}, \mathrm{SiO}_{2}$, $\mathrm{Fe}_{2} \mathrm{O}_{3 \mathrm{t}}, \mathrm{P}_{2} \mathrm{O}_{5}, \mathrm{MnO}, \mathrm{Na}_{2} \mathrm{O}, \mathrm{K}_{2} \mathrm{O}, \mathrm{TiO}_{2}, \mathrm{SrO}$ and loss on ignition (LOI). The chemical analyses were compared with results from the CBN unit by Thomaz (unpublished) and Lee (unpublished) and with results from the $\mathrm{CBF}$ and $\mathrm{CBR}$ units by Ferreira (unpublished).

The CBN units were divided into three correlated facies: Cacfm (fine to medium bedded carbonatite), Carm (bedded carbonatite rich in magnetite), and Cbmg (medium to coarse white carbonatite). The CBF units were also divided into three correlated facies: Cfmc (fine to medium foliated gray carbonatite), Cfox (medium foliated oxidized carbonatite), and Cfba (white foliated carbonatite rich in accessory minerals). The CBR unit was divided into four facies: Cbgm (white coarse massive carbonatite), Cbox (white dolomitic oxidizes carbonatite), Cbma (medium white carbonatite rich in accessory minerals), and Cblm (medium white lamellar carbonatite).

Principal Component Analysis Principal component analysis (PCA) is a mathematical procedure that transforms a number of correlated variables into a number of uncorrelated variables called principal components. The objective of principal component analysis is to reduce the dimensionality of the dataset while retaining the original variability in the data. By an orthogonal linear transformation, PCA transforms the data to a new coordinate system such that the greatest variance falls on the first coordinate (called the first principal component), the second greatest variance on the second coordinate, and so on.

Graphically the procedure can be described as a vector-space transformation that reduces multidimen- sional data to visible 2-dimensional (2D) or 3D space. The analysis starts with eigenvalues (also called latent roots) and the corresponding eigenvector calculation of a correlation matrix or variance-covariance matrix among variables. The initial matrix of similarities based on the Pearson correlation coefficient is the most widely used because this measure removes the scale effect in the data.

The first eigenvalue indicates the highest percentage of the total variability; the second gives the percentage of remaining variability and so forth. The eigenvectors correspond to the principal component and are the result of loading the original variables in each of them. Such loading can be considered as a relative importance measure of each variable regarding the principal component. When multiplied by the original data matrix, the loading matrix of each variable in the principal component provides a score matrix.

After carrying out a PCA, it is possible to simultaneously represent both observations and variables in the same 2D space. The first work on this subject dates from Gabriel (1971). The term biplot is reserved for simultaneous representations in which the projection of observations on variable vectors must be representative of the input data for the same variables. In other words, the projected points on the variable vectors must respect the order and the relative distances of the observations for that same variable in the input data. The simultaneous representation of observations and variables cannot be produced directly by taking the coordinates of the variables and observations in the factor space. A transformation is required to make the interpretation precise.

We used a distance biplot to interpret distances between observations, as these approximate their Euclidean distances in the p-dimensional variable space. The position of two observations projected onto a variable vector can be used to determine their relative level for this variable. Lastly, the length of a variable vector in the representation space is representative of the variable's level of contribution to building this space. The length of the vector is the square root of the sum of the contributions; see the Manual of XLStat (2008).

Discriminant Analysis Discriminant analysis (DA) is a method used to model the extent to which an observation belongs to a group based on the values of several variables. The variables that describe the observations must be quantitative and the groups are distinguished from one another by a categorical variable. Then a given observation is assigned to its most probable group based on the values measured for the variables of that observation. DA may be considered to be an extension of multiple regression in cases where the variable to be explained is a categorical variable that describes the groups; see the Manual of XLStat (2008). This technique constructs a set of linear functions, known as discriminant functions $\mathrm{DF}_{\mathrm{i}}$, such that (eq. 1)

$$
\mathrm{DF}_{\mathrm{i}}=\mathrm{a}_{1} \mathrm{x}_{1}+\mathrm{a}_{2} \mathrm{x}_{2}+\ldots+\mathrm{a}_{\mathrm{n}} \mathrm{x}_{\mathrm{n}}+\mathrm{c}
$$


where the a's are discriminant coefficients, the x's are the input variables or predictors, and $\mathrm{c}$ is a constant.

These discriminant functions are used to predict the class of a new observation $\left(D_{i}\right)$. For a k-class problem k discriminant functions are constructed. Given a new observation, all the $\mathrm{k}$ discriminant functions are evaluated and the observation is assigned to class $i$ if the $\mathrm{i}^{\text {th }}$ discriminant function has the highest value.

The relation between prior and post assignments is frequently reported in a confusion matrix. In this matrix, the number of correctly classified cases lies on the main diagonal while the number of misclassified cases lies on off-diagonals.

The observations used in the discriminant function calculation, as well as the respective centroids from each group, can be plotted in the space defined by the more important discriminant axis. Generally we chose the two discriminant functions of largest weight.

To test the significance of the computed functions, which means to verify whether there are distinct populations, we calculate distances between multivariate averages of two groups. This is known as "the generalized distance of Mahalanobis", or $\mathrm{D}^{2}$, which is used to measure the distance between classes taking into account the covariance structure.

If the covariance matrices are assumed to be equal, the Fisher distances between the classes are displayed. They are calculated from the Mahalanobis distance and are used for a significance test. A matrix of $\mathrm{p}$-values is displayed so as to identify which distances are significant. More details about both methods can be found, among others, in Davis (1986) and Krzanowski (2000). For the application of these methods we used the software XLStat (2008).

RESULTS The sampling locations for the three analyzed groups are shown in figure 2 . At each location we calculated mean grade values for each group and for the chosen coordinates of the vertical drilling holes. For subvertical drilling holes the coordinates correspond to the projection to the surface of the contact between units.

The results from the Principal Component Analysis, using Pearson correlation coefficients matrix, is shown in figure 3 . This diagram shows that the variables are correlated in two clusters: one formed by $\mathrm{MgO}, \mathrm{MnO}, \mathrm{Al}_{2} \mathrm{O}_{3}, \mathrm{SiO}_{2}, \mathrm{P}_{2} \mathrm{O}_{5}$, and $\mathrm{Fe}_{2} \mathrm{O}_{3 \mathrm{t}}$ and the other by LOI, $\mathrm{SrO}, \mathrm{CaO}$, and $\mathrm{S}$. The first cluster has more affinity with the CBN samples while the second has more with the CBR samples. The correlation between variables and CBF is not very clear. In any case, this diagram should be interpreted with caution because the explanation sum supplied for the two principal components is just $61.12 \%$.

The factorial loads of the variables indicate the importance of each variable in the constitution of the two more important principal components. The loading matrix of each variable in the principal, when multiplied by the original data matrix, supplies a score matrix of each observation with respect to the princi-

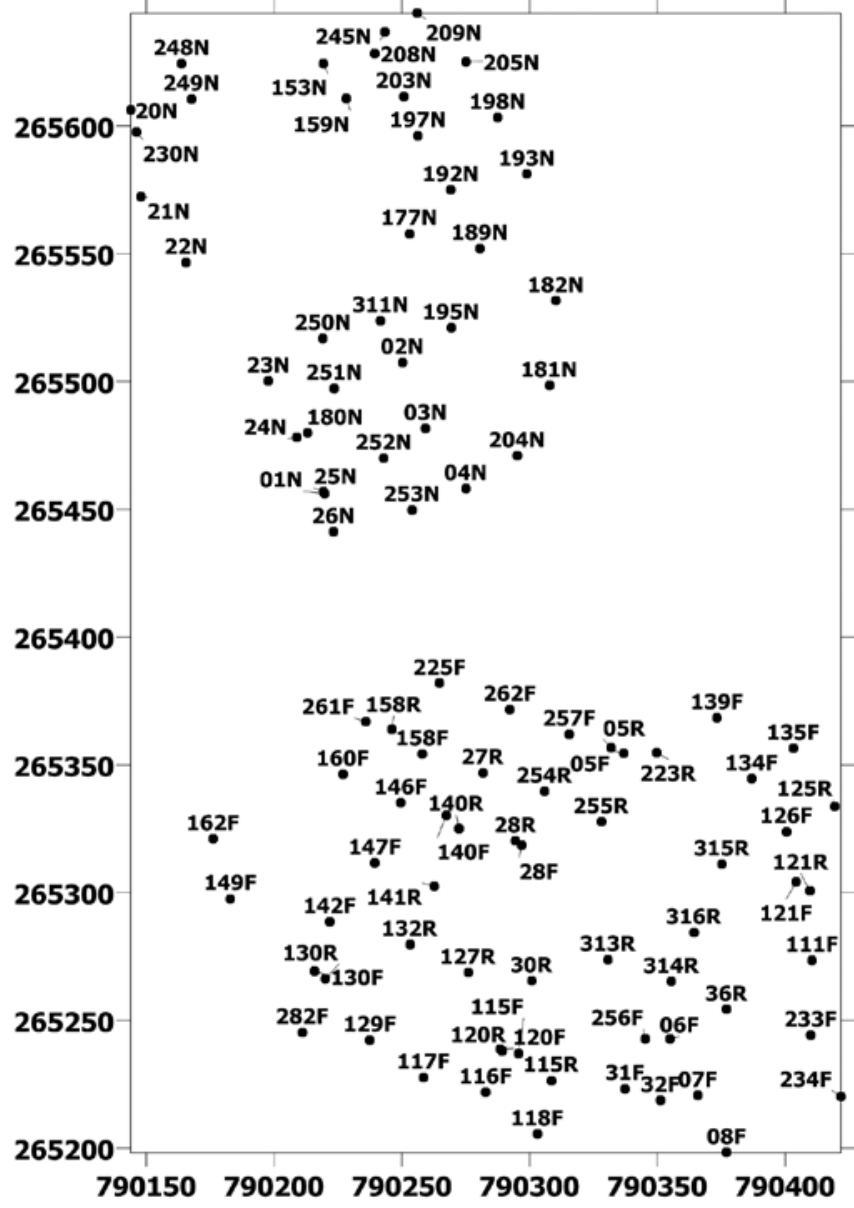

Figure 2 - Location of sampling points.

pal component. Using the geographical coordinates of each observation and, therefore, of the scores, we can construct a distribution map of the first Principal Main Component, as in figure 4.

In this figure samples located in regions of bright colors indicate positive correlations with LOI, $\mathrm{SrO}, \mathrm{CaO}$, and $\mathrm{S}$ and negative correlations with $\mathrm{MgO}$, $\mathrm{MnO}, \mathrm{Al}_{2} \mathrm{O}_{3}, \mathrm{SiO}_{2}, \mathrm{P}_{2} \mathrm{O}_{5}$, and $\mathrm{Fe}_{2} \mathrm{O}_{3}$. The samples located in regions of dark colors indicate opposite situations.

A multigroup discriminant analysis search for centroids of the analyzed groups in the multidimensional space verifies whether the distances among them are statistically significant. By the F test, using the Mahalanobis distances, it was verified that significant discrimination occurs among the three analyzed groups, but the distance is larger between $\mathrm{CBN}$ and $\mathrm{CBF}$ and between CBN and CBR than between CBF and CBR. The graphical results in figure 5 show that overlap zones occur among the three groups; this suggests that some samples were erroneously classified.

As the three groups are discriminated, the samples belonging to each of them can be distributed so as to indicate to what distances they are from the respective centroid. Each observation is classified into the group for the which the probability of belonging 


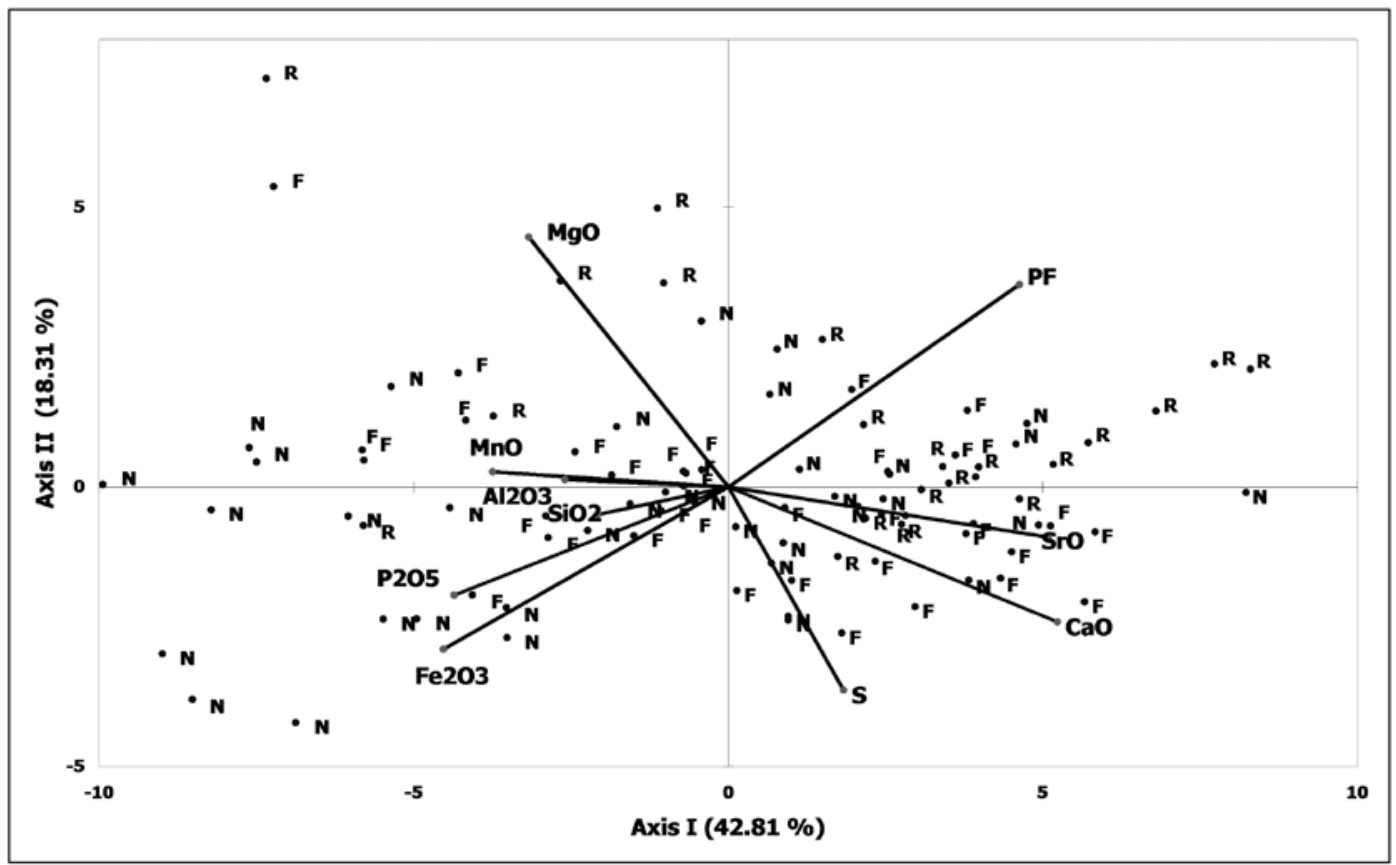

Figure 3 - Biplot Principal Component Analysis, computed from a correlation coefficients matrix, among $C B F$ ( $F$ points), $C B N$ (N points), and CBR ( $R$ points) lithological units.

is the greatest. The probabilities are posterior probabilities that take into account the prior probabilities through the Bayes formula. The results are presented in probabilistic terms; examples appear in table 1 with misclassified samples shown in bold. Using the geographical coordinates of each sample, we built three probability occurrence maps (Fig. 6 to 8 ).

DISCUSSION AND CONCLUSIONS The Principal Component Analysis applied to the data allows us to infer that, from a geochemical point of view, there are some differences among the three carbonatites. Foliated Carbonatite contains $\mathrm{Fe}_{2} \mathrm{O}_{3 \mathrm{t}}, \mathrm{MgO}$, $\mathrm{SiO}_{2}, \mathrm{Al}_{2} \mathrm{O}_{3}$, and $\mathrm{TiO}_{2}$ in higher amounts than the two other units, probably because of the constant presence of silicates such as phlogopite and olivine. The White Carbonatite contains $\mathrm{CaO}$ and $\mathrm{LOI}$ in amounts greater than the other units, suggesting high concentrations of volatiles associated with the initial carbonatite magma, as well as with later hydrothermal fluids.

The modal mineralogical composition is similar for typical facies of CBN and CBF, Cacfm and Cfmc, respectively, with low-significance increases of apatite and magnetite in Cacfm. The principal component analysis shows, see figure 3 , that there is clearly a geochemical affinity among $\mathrm{P}_{2} \mathrm{O}_{5}, \mathrm{Fe}_{2} \mathrm{O}_{3 \mathrm{t}}$, $\mathrm{SiO}_{2}$, and $\mathrm{MnO}$; among $\mathrm{CaO}, \mathrm{SrO}$, and $\mathrm{S}$; and among $\mathrm{MgO}, \mathrm{Al}_{2} \mathrm{O}_{3}$, and $\mathrm{SiO}_{2}$. However, LOI shows a low correlation with $\mathrm{SrO}$.

These relationships among oxides reflect, most of the time, the modal mineralogical compositions of the different faciological units. For apatite

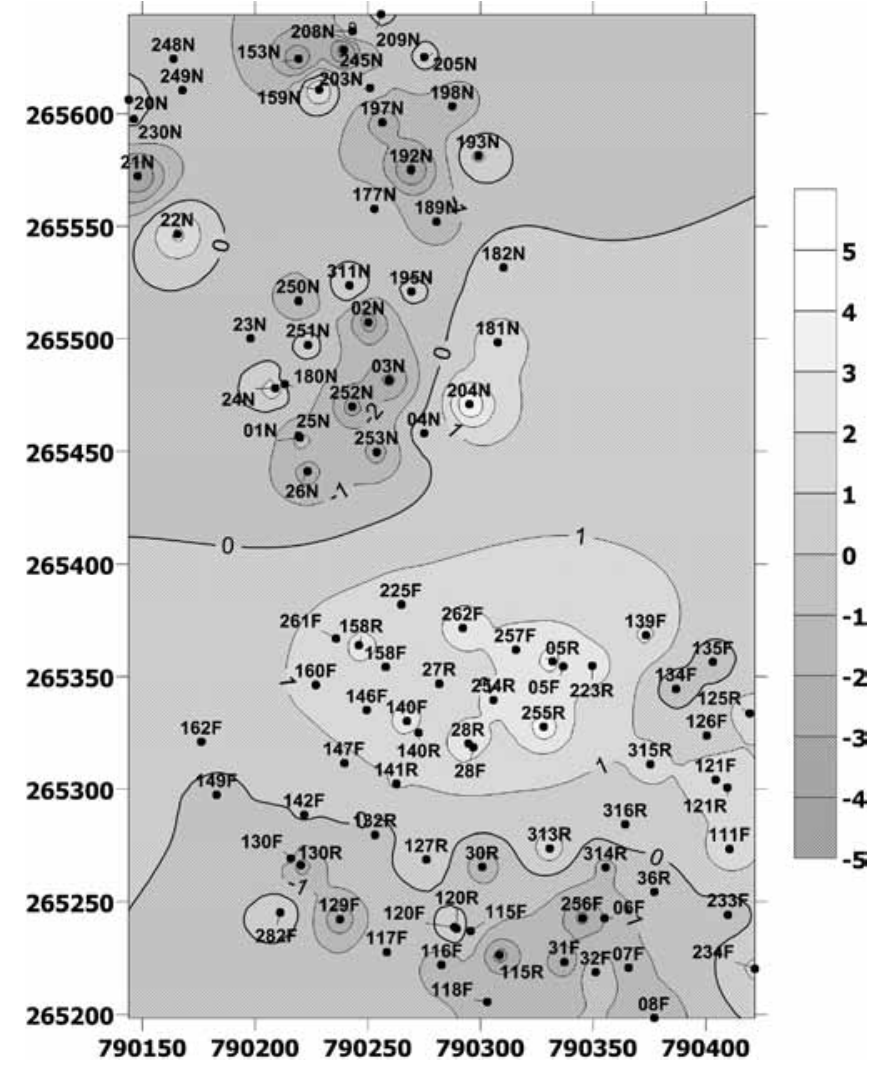

Figure 4 - Spatial distribution of the first Principal Component.

and magnetite $\left(\mathrm{P}_{2} \mathrm{O}_{5}, \mathrm{Fe}_{2} \mathrm{O}_{3 \mathrm{t}}\right.$, and $\left.\mathrm{MnO}\right)$ during the field survey and borehole core descriptions, it was 


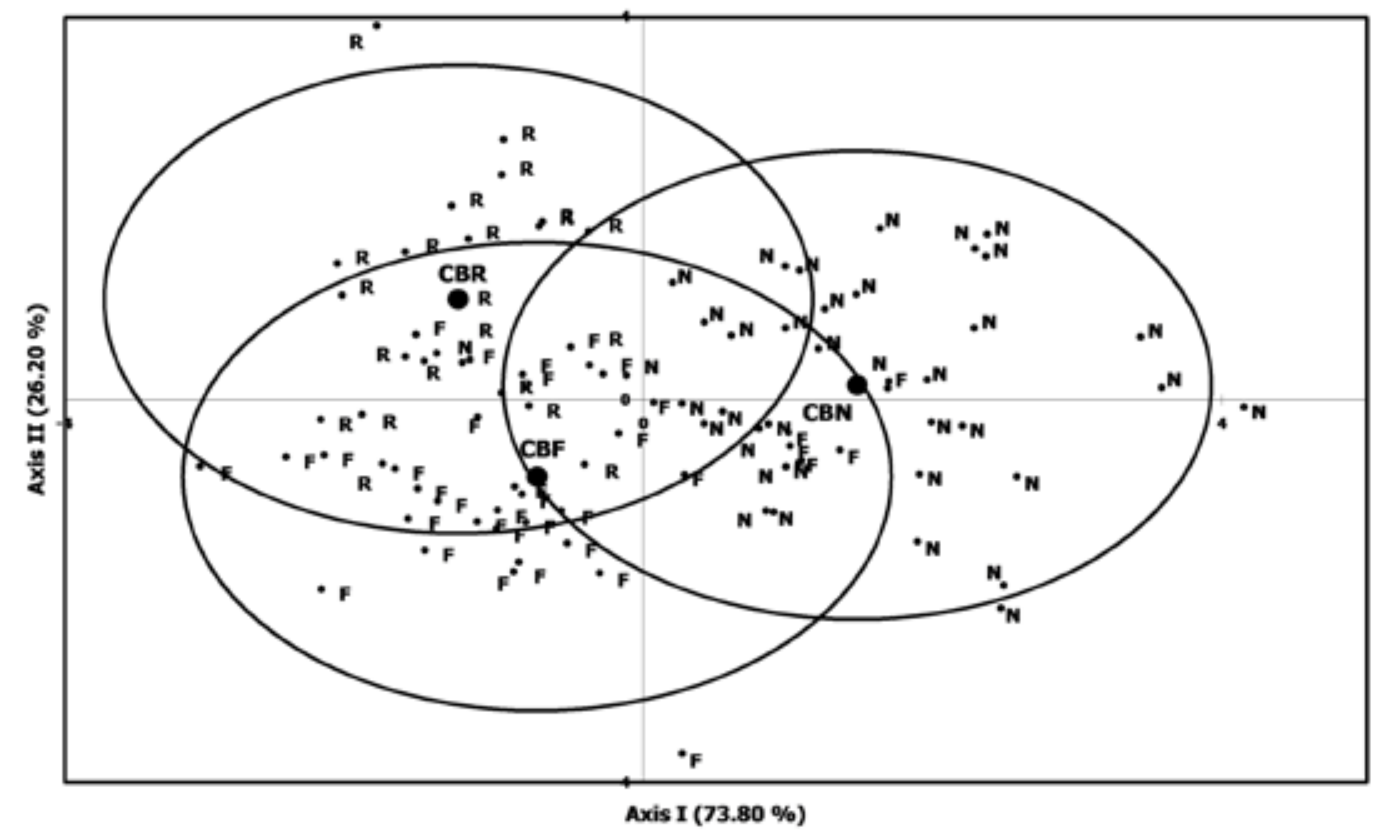

Figure 5 - Multigroup discriminant analysis among $C B F$ ( $F$ points), $C B N$ ( $N$ points), and CBR (R points) lithological units. (•): group centroids.

Table 1 - Identification of the samples, XY coordinates of the samples, prior-classification, post-classification, membership probability, and squared distances to the group centroids.

\begin{tabular}{c|c|c|c|c|c|c|c|c|c|c}
\hline ID & $\mathrm{X}$ & $\mathrm{Y}$ & Prior & Post & Prob. CBF & Prob. CBN & Prob. CBR & $\mathrm{d}^{2}(\mathrm{i}, \mathrm{CBF})$ & $\mathrm{d}^{2}(\mathrm{i}, \mathrm{CBN})$ & $\mathrm{d}^{2}(\mathrm{i}, \mathrm{CBR})$ \\
\hline $05 \mathrm{~F}$ & 790336.77 & 265354.57 & $\mathrm{CBF}$ & $\mathrm{CBF}$ & 0.479 & 0.409 & 0.112 & 11.121 & 11.491 & 13.038 \\
\hline $06 \mathrm{~F}$ & 790355.05 & 265242.68 & $\mathrm{CBF}$ & $\mathrm{CBF}$ & 0.890 & 0.007 & 0.103 & 8.572 & 18.291 & 11.897 \\
\hline $07 \mathrm{~F}$ & 790365.83 & 265220.6 & $\mathrm{CBF}$ & $\mathrm{CBF}$ & 0.966 & 0.014 & 0.020 & 4.315 & 12.883 & 11.038 \\
\hline $08 \mathrm{~F}$ & 790377.1 & 265198.33 & $\mathrm{CBF}$ & $\mathrm{CBN}$ & 0.200 & 0.790 & 0.009 & 7.579 & 4.891 & 12.742 \\
\hline $111 \mathrm{~F}$ & 790410.57 & 265273.55 & $\mathrm{CBF}$ & $\mathrm{CBF}$ & 0.928 & 0.004 & 0.068 & 2.995 & 13.993 & 7.238 \\
\hline $115 \mathrm{~F}$ & 790295.58 & 265237.04 & $\mathrm{CBF}$ & $\mathrm{CBF}$ & 0.963 & 0.005 & 0.032 & 5.039 & 15.573 & 10.877 \\
\hline $116 \mathrm{~F}$ & 790282.81 & 265221.91 & $\mathrm{CBF}$ & $\mathrm{CBF}$ & 0.901 & 0.039 & 0.060 & 4.896 & 11.229 & 9.342 \\
\hline $117 \mathrm{~F}$ & 790258.51 & 265227.7 & $\mathrm{CBF}$ & $\mathrm{CBF}$ & 0.926 & 0.017 & 0.057 & 4.333 & 12.439 & 8.911 \\
\hline $118 \mathrm{~F}$ & 790303.04 & 265205.53 & $\mathrm{CBF}$ & $\mathrm{CBF}$ & 0.716 & 0.000 & 0.284 & 27.940 & 43.753 & 28.805 \\
\hline $120 \mathrm{~F}$ & 790288.47 & 265238.73 & $\mathrm{CBF}$ & $\mathrm{CBF}$ & 0.946 & 0.015 & 0.039 & 2.347 & 10.676 & 7.718 \\
\hline $121 \mathrm{~F}$ & 790404.35 & 265304.28 & $\mathrm{CBF}$ & $\mathrm{CBF}$ & 0.970 & 0.014 & 0.016 & 4.081 & 12.677 & 11.281 \\
\hline $126 \mathrm{~F}$ & 790400.46 & 265323.9 & $\mathrm{CBF}$ & $\mathrm{CBF}$ & 0.909 & 0.007 & 0.083 & 6.219 & 15.949 & 10.012 \\
\hline $129 \mathrm{~F}$ & 790237.55 & 265242.33 & $\mathrm{CBF}$ & $\mathrm{CBF}$ & 0.939 & 0.050 & 0.011 & 6.308 & 12.219 & 14.246 \\
\hline $130 \mathrm{~F}$ & 790215.93 & 265269.38 & $\mathrm{CBF}$ & $\mathrm{CBF}$ & 0.735 & 0.001 & 0.264 & 19.667 & 32.843 & 20.733 \\
\hline $134 \mathrm{~F}$ & 790386.87 & 265344.53 & $\mathrm{CBF}$ & $\mathrm{CBN}$ & 0.170 & 0.820 & 0.010 & 8.787 & 5.700 & 13.478 \\
\hline $135 \mathrm{~F}$ & 790403.18 & 265356.4 & $\mathrm{CBF}$ & $\mathrm{CBN}$ & 0.034 & 0.962 & 0.005 & 41.789 & 35.142 & 44.733 \\
\hline$\ldots$ & $\ldots$ & $\ldots$ & $\ldots$ & $\ldots$ & $\ldots$ & $\ldots$ & $\ldots$ & $\ldots$ & $\ldots$ & $\ldots$ \\
\hline
\end{tabular}

noted that these minerals exhibit a positive correlation. In other words, for an increase in magnetite there is a proportional increase in apatite.

The results obtained by discriminant analysis show a clear distinction between grade values expressed by the units CBN and CBF, these being considered distinct units, as well as the relation between the units CBR and CBN. Regarding the units CBF and $\mathrm{CBR}$, there were no striking differences regarding the sample distributions, and both faciological units pres- ent the same behavior for the analyzed oxides.

The 120R, 121R, 27R, 08F, 05F, 134F, 147F, 160F, 282F, 140R, and 141R samples showed discordant chemical compositions relative to that expected for the corresponding faciological units. But these are just eleven dissonant samples from the total of 95 samples. This disagreement is demonstrated through the discriminant analysis, which verifies the analyzed variables and clusters among the samples into distinct populations. When a sample 


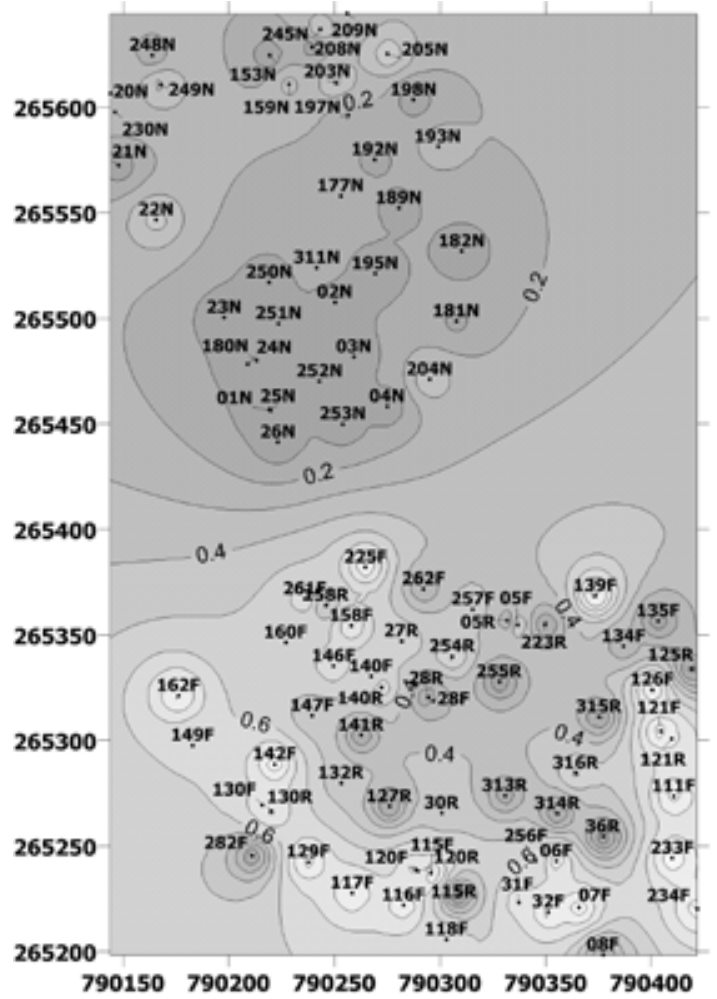

Figure 6 - Occurrence probability distribution for lithological unit $C B F$.

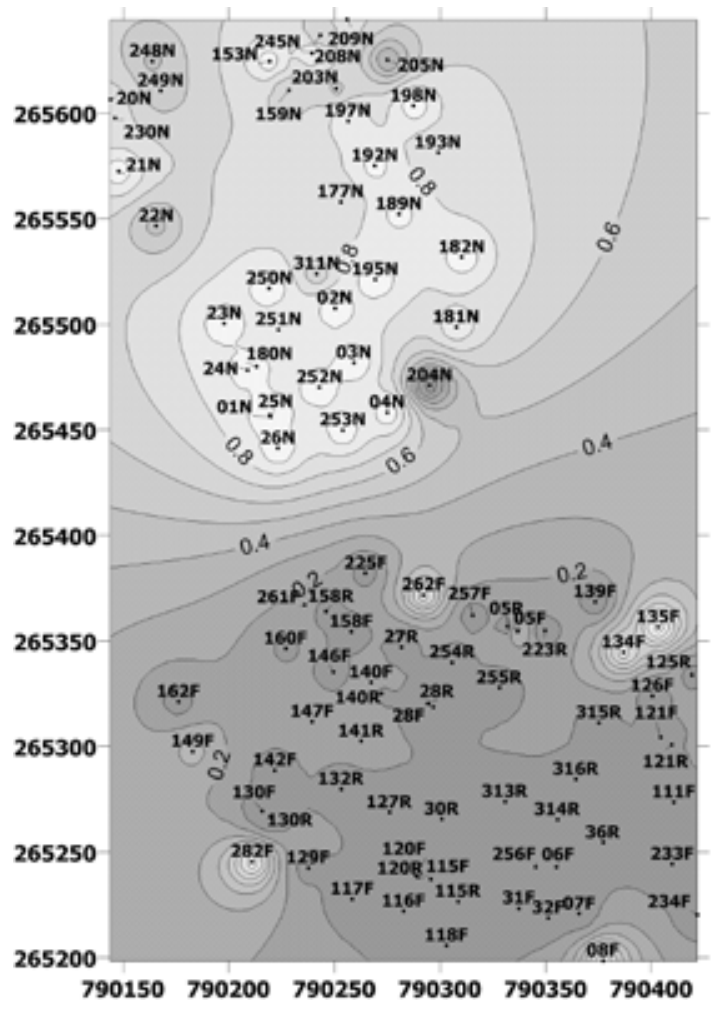

Figure 7 - Occurrence probability distribution for lithological unit $C B N$.

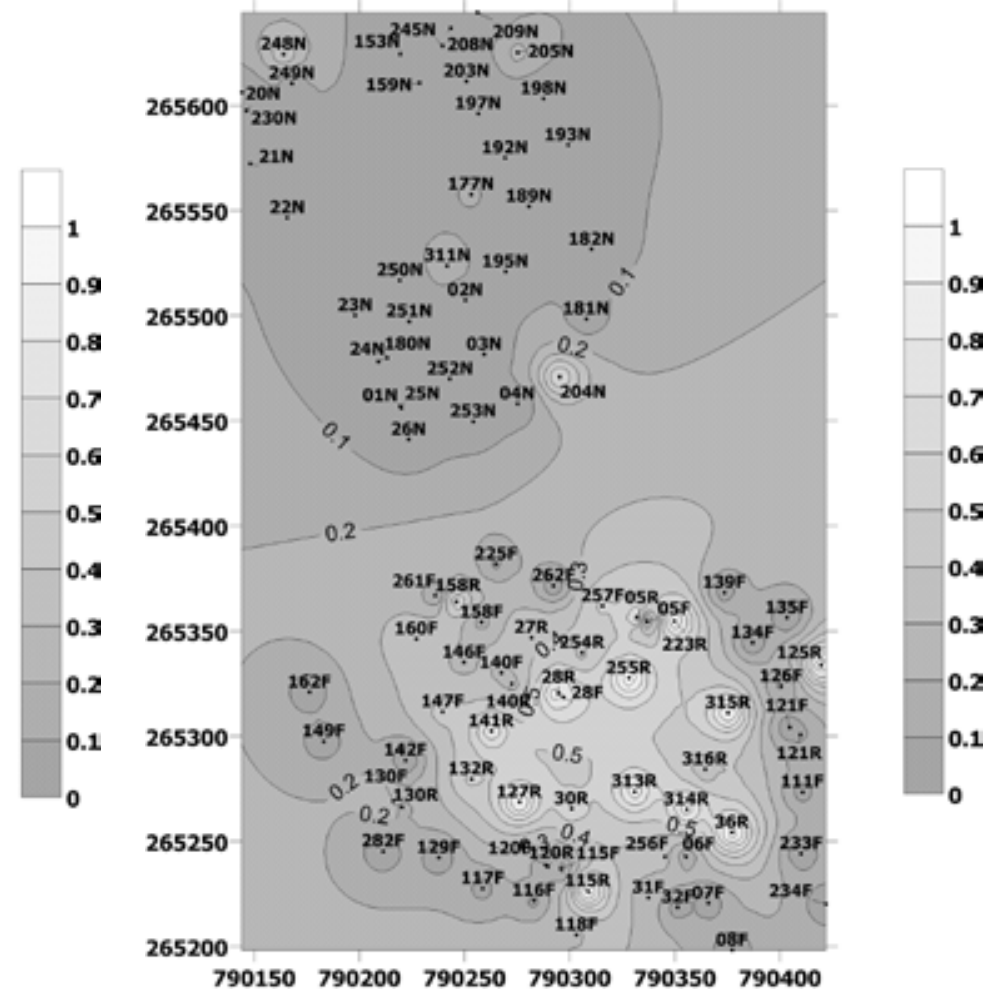

Figure 8 - Occurrence probability distribution for lithological unit CBR.

presents a divergent position in relation to that of the unit to which belongs, we can infer either a sampling mistake, or contamination, or the presence of another rock with similar composition. The discordant eleven samples might be explained by different rock interbedding that was distinct from the typical facies to which they belong. Such interbedding can be dolomitic zones, apatite-rich zones, zones rich in magnetite and apatite, or reaction zones with a preponderance of silicatic minerals. In the CBN sample distribution map (Fig. 7), it is possible to distinguish small areas having geochemical behavior similar to that of the CBF zone. One of the more probable factors for such occurrences would be caused by strong fluid-rock interactions in the contact between CBR and $\mathrm{CBF}$ zones, rich in $\mathrm{CO}_{2}$ and $\mathrm{MgO}$. Similar processes in the contact between the CBN unit and the CDOL (Dolomitic Carbonatite) intrusive body were originated mostly from fluid-rock interactions of distinct magmas.

Thus from the mining point of view it is clear that the two faciologic units $\mathrm{CBF}$ and $\mathrm{CBN}$ constitute distinct units that cannot be evaluated concomitantly because they represent different populations with respect to the oxide contents. However, the CBR unit, which has intimate connection with $\mathrm{CBF}$, which was verified as much in the field as by discriminant analysis, does not require a differentiated quarry.

The work developed by Ferreira (unpublished) supplied an overview of the textural and com- 
positional mineralogical characteristics of the main faciologic units studied here. From the facies spatial arrangement and from geological surveying, it was inferred that in the contact between Foliated Carbonatite and White Carbonatite, and also between North Carbonatite and Dolomitic Carbonatite, transition zones occur. The interbedding of lithotypes and the occurrence of dolomitic bodies are quite common and make delimitation difficult. This complicates lithotype separation during sampling. Sometimes the presence of various lithotypes can be verified in the same sample. This complicated sampling situation can be modeled, as seen in this work, by applying regionalized classification that supplies occurrence maps on a probabilistic basis. In this way the method becomes a predictive modeling of lithotypes and lithofacies.

Acknowledgments To Bunge Fertilizers S. A. Brazil, for allowing the use of these data, which were obtained when co-author Talita C. de O. Ferreira did work for completion of her undergraduate degree in Geology. To L.V. Thomaz, T. Lee and T.C.O. Ferreira for relevant geological and geochemical information regarding Cajati Mine. Thanks also to the anonymous reviewer for critically reading the paper and making constructive comments.

\section{References}

Bohling G.C. 1997. GSLIB-Style Programs for Discriminant Analysis and Regionalized Classification. Computers \& Geosciences, 23(7):739-761.

Davis J.C. 1986. Statistics and Data Analysis in Geology. $2^{\text {nd }}$ ed., New York, John Wiley and Sons.

Gabriel K.R. 1971. The biplot graphic display of matrices with application to principal component analysis. Biometrika, 58:453-467.

Gaspar J.C. 1989. Geologie et mineralogie du complexe carbonatitique de Jacupiranga, Brésil. França, Thèse de doctorat, U.E.R. de Science Fundamentales et Appliquées, Université d'Orleans, $344 \mathrm{p}$.

Harff J., Davis J.C. 1990. Regionalization in geology by multivariate classification. Mathematical Geology, 22(5):577-588.

Krzanowski W.J. 2000. Principles of Multivariate Analysis. A User's Perspective. New York, Oxford University Press,

Melcher G.C. 1962. O Carbonatito de Jacupiranga, Estado de São Paulo. São Paulo, PhD Thesis, Instituto de Geociências, USP, $59 \mathrm{p}$.

Olea R.A. 1999. Geostatistics for Engineers and Earth Sci- entists. Kluwer Academic Publishers, ch. 14, Norwell, MA.

Pacheco F.A.L. \& Landim P.M.B. 2005. Two-Way Regionalized Classification of Multivariate Datasets and its Application to the Assessment of Hydrodynamic Dispersion. Mathematical Geology, 37(I4):393-417.

Ruberti E., Marguti R.L., Gomes C.B. 1992. O Complexo carbonatítico de Jacupiranga, SP: Informações gerais. In: SBG/SP, Congresso Brasileiro de Geologia, 37, São Paulo, SP, Roteiro das excursões, 4:16.

Saito M.M., Barros T.B., Bettencourt J.S. 2004. Mapeamento geológico de detalhe da mina de Cajati (SP): modelo conceitual e aplicação à lavra, produção e beneficiamento. In: SBG-MG, Congresso Brasileiro de Geologia, 42, Araxá, Anais, CD-Rom.

XLSTAT 2008. Addinsoft, Paris, France. Available from: http://www.xlstat.com.

Manuscrito ID 14775

Submetido em 14 de julho de 2009

Aceito em 01 de junho de 2010 